\title{
Database Coverage for Research in Management Information Systems
}

\section{Karen Chapman and Paul Brothers}

This study examines the database coverage of management information systems (MIS) journals and journal articles referenced by MIS researchers. Lists of titles and references were checked for coverage in twelve databases representing a variety of vendors: five multidisciplinary databases, four business databases, and three computer science or applied science databases. The best coverage of MIS journals is found in ABI/INFORM Global and Business Source Premier. The best coverage of articles referenced by MIS scholars is offered by the same two databases, although Business Source Premier offers significantly more full text. Business Source Premier and Web of Science provide the best coverage for any pair of the databases.

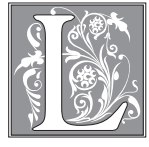

ibrarians are not the only ones who know the value of information; managers in business areas from accounting to manufacturing to marketing have known for years that the right information about products, processes, and customers can help them make better management decisions. Management information systems (MIS) is the field that studies the use of information in business - what information is needed, how to get it, and how to use it. MIS focuses on the application of computer systems to business processes and, more broadly, how technology can be used effectively and efficiently to achieve the goals of the organization. ${ }^{1}$ This includes study of the interface between the user and the system and the effects on each. ${ }^{2}$

MIS scholars have tracked the development of their field of study as it has evolved into a discipline. It began to take shape during the 1960s, and MIS Quar- terly, the first journal in the discipline, was founded in 1977. ${ }^{3}$ The First International Conference on Information Systems was held in 1980, and the Association for Information Systems was established in 1994. ${ }^{4,5}$ More than a hundred universities have graduate or undergraduate programs in MIS. ${ }^{6}$ Today, MIS has "a distinct subject matter, a distinct research perspective, and a well-developed communication system that includes respected journals."

Because of the nature of the discipline and its relatively recent development, MIS scholars continue to draw on research in other disciplines. Richard L. Baskerville and Michael D. Myers provided a quick overview of the development of thought related to MIS's reference disciplines; they point out that early MIS research draws heavily on engineering, computer science, cybernetic systems theory, mathematics, management science, and behavioral decision theory. More recent suggestions have included disciplines as diverse as ar-

Karen Chapman and Paul Brothers are both Business Reference Librarians in the Angelo Bruno Business Library at the University of Alabama; e-mail: kchapman@bruno.cba.ua.edu and pbrother@bruno.cba.ua.edu. 
chitecture and anthropology. ${ }^{8}$ Iris Vessey, V. Ramesh, and Robert L. Glass analyzed articles from five MIS journals for the period 1995 through 1999. They classified the reference disciplines of MIS into these categories: cognitive psychology, social and behavioral science, computer science, economics, information systems, management, management science, and other. They found that information systems, management, and economics were the most common reference disciplines cited by authors of the articles in their study. ${ }^{9}$ Karen Chapman and Paul Brothers analyzed references from articles in three leading MIS journals for the period 2000 through 2002. A random sample of the references to journal articles was taken, and each reference was classified by subject according to the journal's primary subject matter. Management was the most frequently referenced subject, followed closely by MIS itself; other subjects with notable numbers of references were "computing and technology" and "psychology and sociology." 10

The purpose of this study is to examine database coverage for the discipline of MIS. Because of the continuing reliance of MIS on research in other fields, the study has been divided into two parts. The first part focuses on coverage of journals that publish MIS research. The second part focuses on coverage of the journal resources used by MIS scholars in producing their research.

\section{Literature Review}

Bibliographic databases have assumed a prominent position in library collections, and the library literature contains numerous studies that compare databases or analyze their content. A subset of these studies focuses on database coverage within a particular subject area. Steve Black analyzed the social sciences coverage of four general databases by comparing their title lists to the list of titles covered by the Social Sciences Citation Index, as reported in Journal Citation Reports. He compared the quality of the coverage by computing the average impact factor for the set of titles included in each database. ${ }^{11}$

Michael Colby studied the coverage of music periodicals in six general and one humanities database. His list of music periodicals was derived from the title coverage lists of two prominent music databases. His study compared coverage overall, by type of journal, by language, and by music subfield. ${ }^{12}$ Péter Jacsó developed a methodology for studying database coverage of journals by counting numbers of records in the databases and used it to examine coverage of forty-two library and information science journals in six databases for a specified time period. ${ }^{13}$ Chapman's study compared coverage of the field of finance in three general business databases. Instead of using title lists, she retrieved references from the articles in leading finance journals and searched for those items in the databases. Her results reported numbers of items not covered, indexed only, or available full text. ${ }^{14}$ William H. Walters and Esther I. Wilder examined the bibliographic database coverage of later-life migration, a multidisciplinary field of study. They discovered that multidisciplinary databases provided more comprehensive coverage of the field than subject-specific databases and that multiple databases must be searched to identify all the literature in the field. ${ }^{15}$

Although information systems is a topic that pervades much of the library literature, the academic discipline of management information systems has received little attention. Jinjg $\mathrm{Hu}$, Lai $\mathrm{C}$. Liu, Kai S. Koong, and Lillian Fok studied the holdings of MIS journals at the libraries of universities with MIS programs. The journals then were ranked by the number of libraries where each was held. ${ }^{16}$ In their study mentioned previously, Chapman and Brothers also analyzed the references gathered from articles in three leading MIS journals in order to profile the types of materials used by MIS researchers. They found that about 65 percent of ref- 
erences were journal articles and about 25 percent were books or book chapters. Further examination of a sample of the journal article references showed that 93 percent were published since $1980 .{ }^{17}$

MIS scholars have studied their own literature extensively, and several articles have attempted to define the "top" journals in the field. The results of six of these studies are compared in a table on the Journal Rankings page at ISWorld Net. A bibliography of additional studies also is given. ${ }^{18}$ The two most common methodologies are surveys of academics and/or practitioners and citation analyses. ${ }^{19}$

\section{MIS Journals Examined}

Many of the journals identified by MIS researchers as among the top-ranked titles in MIS have other fields as their primary focus. For example, Harvard Business Review, identified as among the top ten MIS journals in at least six studies, is typically considered a management journal. ${ }^{20}$ To identify a list of journals that are important to MIS researchers, the authors turned to Kent A. Walstrom and Bill C. Hardgrave's 2001 report on a survey of MIS faculty. The 364 survey respondents rated each of fifty-one journals in several ways. One question asked respondents to rate a journal's importance as a publication outlet on a scale of one to four. Overall scores were computed, and journals were ranked accordingly. A natural break occurred in the scores after the twentieth title, and the authors selected the top twenty titles as the basis for investigation. ${ }^{21}$

The next step in the process was to confirm that all twenty titles were still active and to check for possible title changes. WorldCat and Ulrich's International Periodicals Directory were consulted for each title. All the titles were active under the title shown in the list, with one minor exception. Table 1 shows the complete list of MIS journals used in the study, along with the ISSN, publisher and sponsor, year founded, and frequency for each title. Eleven of the titles are published by scholarly or professional associations, and three are sponsored by an association, but published by a commercial publisher. Two more are published solely by a commercial publisher, and four are published by a university division or publisher. Founding dates range from 1922 for Harvard Business Review to 1991 for European Journal of Information Systems. For the most part, founding dates are evenly distributed across the decades of the 1950s through the 1990s.

\section{Databases Examined}

Elaine Wagner argued that librarians should be aware of subject coverage in databases "beyond the obvious." 22 Because of this field's close ties to management and computer science, the authors selected databases from these fields, as well as multidisciplinary databases, to examine for coverage of MIS publications. Table 2 shows the list of databases, with each database's vendor or producer, number of titles covered, number of titles covered full text, and general subject category as assigned by the authors. The list includes five multidisciplinary databases, four business databases, and three computer science or applied science databases.

As demonstrated in table 2, the authors selected databases from a range of vendors in the various categories. Major vendors are well represented in the list, with three titles from EBSCO Information Services, two from ProQuest Information and Learning, and three from Thomson Gale. The list is rounded out with both specialty database vendors, such as Dow Jones/Reuters, and other vendors with products across multiple disciplines, such as $\mathrm{H}$. W. Wilson. The sizes of the various databases also vary dramatically, from coverage of 441 titles for Computer Source to coverage of more than 9,000 for Business Source Premier. Finally, full-text coverage also varies widely. Although it is convenient to find the full text of an article available in a database, a good researcher uses indexes and databases that lead to the best results, not just those that offer full text. 
Database Coverage for Research in Management Information Systems 53

\begin{tabular}{|c|c|c|c|c|}
\hline \multicolumn{5}{|c|}{$\begin{array}{c}\text { TABLE } 1 \\
\text { Journals Included in the Study }\end{array}$} \\
\hline Journal Title & ISSN & Publisher/Sponsor & $\begin{array}{c}\text { Year } \\
\text { Founded }\end{array}$ & Frequency \\
\hline $\begin{array}{l}\text { Academy of } \\
\text { Management Journal }\end{array}$ & $0001-4273$ & Academy of Management & 1958 & Bimonthly \\
\hline $\begin{array}{l}\text { Academy of } \\
\text { Management Review }\end{array}$ & $0363-7425$ & Academy of Management & 1976 & Quarterly \\
\hline $\begin{array}{l}\text { ACM Computing } \\
\text { Surveys }\end{array}$ & 0360-0300 & $\begin{array}{l}\text { Association for Computing } \\
\text { Machinery }\end{array}$ & 1969 & Quarterly \\
\hline $\begin{array}{l}\text { ACM Transactions on } \\
\text { Database Systems }\end{array}$ & $0362-5915$ & $\begin{array}{l}\text { Association for Computing } \\
\text { Machinery }\end{array}$ & 1976 & Quarterly \\
\hline $\begin{array}{l}\text { ACM Transactions on } \\
\text { Information Systems }\end{array}$ & $1046-8188$ & $\begin{array}{l}\text { Association for Computing } \\
\text { Machinery }\end{array}$ & 1983 & Quarterly \\
\hline $\begin{array}{l}\text { Administrative Science } \\
\text { Quarterly }\end{array}$ & $0001-8392$ & $\begin{array}{l}\text { Johnson Graduate School } \\
\text { of Management, Cornell } \\
\text { University }\end{array}$ & 1956 & Quarterly \\
\hline $\begin{array}{l}\text { Communications of the } \\
\text { ACM }\end{array}$ & 0001-0782 & $\begin{array}{l}\text { Association for Computing } \\
\text { Machinery }\end{array}$ & 1958 & Monthly \\
\hline Decision Sciences & $0011-7315$ & $\begin{array}{l}\text { Blackwell/Decision Sciences } \\
\text { Institute }\end{array}$ & 1970 & Quarterly \\
\hline $\begin{array}{l}\text { Decision Support } \\
\text { Systems }\end{array}$ & $0167-9236$ & Elsevier & 1985 & 8/year \\
\hline $\begin{array}{l}\text { European Journal of } \\
\text { Information Systems }\end{array}$ & 0960-085X & $\begin{array}{l}\text { Palgrave Macmillan/ } \\
\text { Operational Research Society }\end{array}$ & 1991 & Quarterly \\
\hline $\begin{array}{l}\text { Harvard Business } \\
\text { Review }\end{array}$ & 0017-8012 & $\begin{array}{l}\text { Harvard Business School } \\
\text { Publishing }\end{array}$ & 1922 & Monthly \\
\hline $\begin{array}{l}\text { IEEE Transactions on } \\
\text { Knowledge and Data } \\
\text { Engineering }\end{array}$ & $1041-4347$ & $\begin{array}{l}\text { Institute of Electrical and } \\
\text { Electronics Engineers (IEEE) }\end{array}$ & 1989 & Monthly \\
\hline $\begin{array}{l}\text { IEEE Transactions on } \\
\text { Software Engineering }\end{array}$ & 0098-5589 & IEEE/Computer Society & 1975 & Monthly \\
\hline $\begin{array}{l}\text { Information \& } \\
\text { Management }\end{array}$ & 0378-7206 & $\begin{array}{l}\text { Elsevier/International } \\
\text { Federation for Information } \\
\text { Processing (AT) Applied } \\
\text { Information Group }\end{array}$ & 1968 & 8/year \\
\hline $\begin{array}{l}\text { Information Systems } \\
\text { Research }\end{array}$ & $1047-7047$ & INFORMS & 1990 & Quarterly \\
\hline $\begin{array}{l}\text { Journal of Management } \\
\text { Information Systems }\end{array}$ & $0742-1222$ & M. E. Sharpe, Inc. & 1984 & Quarterly \\
\hline Management Science & 0025-1909 & INFORMS & 1954 & Monthly \\
\hline MIS Quarterly & $0276-7783$ & $\begin{array}{l}\text { Management Information } \\
\text { Systems Research Center, } \\
\text { University of Minnesota }\end{array}$ & 1977 & Quarterly \\
\hline $\begin{array}{l}\text { MIT Sloan } \\
\text { Management Review }\end{array}$ & $1532-9194$ & $\begin{array}{l}\text { Massachusetts Institute of } \\
\text { Technology/Sloan Management } \\
\text { Review Association }\end{array}$ & 1960 & Quarterly \\
\hline Organization Science & $1047-7039$ & INFORMS & 1990 & Quarterly \\
\hline
\end{tabular}




\begin{tabular}{|c|c|c|c|c|}
\hline \multicolumn{5}{|c|}{$\begin{array}{c}\text { TABLE } 2 \\
\text { Databases Included in the Study }\end{array}$} \\
\hline Database Name & Vendor/Producer & $\begin{array}{c}\text { Titles } \\
\text { Covered } \\
\text { (no.) }\end{array}$ & $\begin{array}{c}\text { Titles } \\
\text { Covered } \\
\text { Full Text } \\
\text { (no.) }\end{array}$ & Subject \\
\hline $\begin{array}{l}\text { ABI/INFORM } \\
\text { Global }\end{array}$ & $\begin{array}{l}\text { ProQuest Information } \\
\text { and Learning }\end{array}$ & 1,600 & 700 & Business \\
\hline $\begin{array}{l}\text { Academic Search } \\
\text { Premier }\end{array}$ & $\begin{array}{l}\text { EBSCO Information } \\
\text { Services }\end{array}$ & 8,200 & 4,681 & Multidisciplinary \\
\hline $\begin{array}{l}\text { Applied Science \& } \\
\text { Technology Full Text }\end{array}$ & H. W. Wilson & 751 & 174 & Applied Science \\
\hline $\begin{array}{l}\text { Business \& Company } \\
\text { Resource Center }\end{array}$ & Thomson Gale & 3,689 & 2,825 & Business \\
\hline $\begin{array}{l}\text { Business Source } \\
\text { Premier }\end{array}$ & $\begin{array}{l}\text { EBSCO Information } \\
\text { Services }\end{array}$ & 9,028 & 8,167 & Business \\
\hline Computer Database & Thomson Gale & 665 & 361 & Computer Science \\
\hline Computer Source & $\begin{array}{l}\text { EBSCO Information } \\
\text { Services }\end{array}$ & 441 & 315 & Computer Science \\
\hline $\begin{array}{l}\text { Expanded Academic } \\
\text { ASAP }\end{array}$ & Thomson Gale & 3,723 & 2,203 & Multidisciplinary \\
\hline Factiva & Dow Jones/Reuters & 9,000 & n.a. & Business \\
\hline LexisNexis Academic & LexisNexis & 5,600 & n.a. & Multidisciplinary \\
\hline $\begin{array}{l}\text { ProQuest Research } \\
\text { Library }\end{array}$ & $\begin{array}{l}\text { ProQuest Information } \\
\text { and Learning }\end{array}$ & 3,000 & 1,900 & Multidisciplinary \\
\hline Web of Science & Thomson ISI & 8,700 & 0 & Multidisciplinary \\
\hline
\end{tabular}

\section{Database Coverage of MIS Research}

The list of twenty journals that are important publication outlets for MIS research was first checked online for coverage in each database. Each title was coded as not covered, indexed only, or full text available. The title was coded as full text if any issues were available full text, regardless of their date. Table 3 shows the results by journal. The most frequently covered journal on the list is IEEE Transactions on Software Engineering, which is indexed in eleven of the twelve databases, but not full text in any. The journal with the least coverage is Academy of Management Review, which is covered in four of the databases. On average, each title is covered in seven of the twelve databases.

Next the databases were ranked by number of titles covered, followed by number of titles with full text. Table 4 shows the results. Three databases cover all twenty journals: Business Source Premier, Expanded Academic Index, and Web of Science. Business Source Premier offers full text for fourteen journals and Expanded Academic Index for thirteen, so they are ranked first and second. ABI/INFORM Global and Business \& Company Resource Center have good coverage, with eighteen and seventeen titles covered respectively. LexisNexis Academic has by far the poorest coverage, not covering any of the titles on the list.

Simple title counts can be informative, but they do not capture the complexity of database coverage. Other factors also are important: Is the title indexed selectively or thoroughly? When did coverage begin? Are there gaps? Is coverage still 
active? Jacsó pointed out these and other important considerations in his article on database coverage of library and information science journals. His methodology involved counting numbers of records for the journals within each database and comparing the results across the set of databases. He looked at four combinations of journals and date ranges: all journals for all years and for recent years, then top journals for all years and for recent years. ${ }^{23}$ The authors adopted this approach. The number of hits in the database was recorded for each journal, both overall and from 2000 to the present. Results for the individual journals were added together to arrive at a total for the database. Note that this is not an entirely accurate method of gauging level of coverage; in particular, duplicate records for the same article can inflate the results. For example, when databases have added full-text backfiles, the records containing the full text may have simply been added to the database, even though records were already in the database containing the bibliographic information for those articles.

The first line in table 5 gives the results for all twenty titles for their full existence. The authors compiled previous title information for the journals from Ulrich's International Periodicals Directory database and WorldCat and included the previous titles in their counts. The second line gives the data as a percentage of the

\begin{tabular}{|c|c|c|c|}
\hline \multicolumn{4}{|c|}{$\begin{array}{c}\text { TABLE } 3 \\
\text { Journal Coverage in Selected Databases }(N=12)\end{array}$} \\
\hline Journal Title & $\begin{array}{c}\text { Indexed } \\
\text { Only (no.) }\end{array}$ & $\begin{array}{l}\text { Full Text } \\
\text { (no.) }\end{array}$ & $\begin{array}{c}\text { Total Coverage } \\
\text { (no.) }\end{array}$ \\
\hline Academy of Management Journal & 2 & 5 & 7 \\
\hline Academy of Management Review & 2 & 2 & 4 \\
\hline ACM Computing Surveys & 3 & 6 & 9 \\
\hline ACM Transactions on Database Systems & 6 & 4 & 10 \\
\hline ACM Transactions on Information Systems & 7 & 3 & 10 \\
\hline Administrative Science Quarterly & 2 & 5 & 7 \\
\hline Communications of the ACM & 4 & 5 & 9 \\
\hline Decision Sciences & 3 & 3 & 6 \\
\hline Decision Support Systems & 7 & 0 & 7 \\
\hline European Journal of Information Systems & 5 & 2 & 7 \\
\hline Harvard Business Review & 3 & 3 & 6 \\
\hline $\begin{array}{l}\text { IEEE Transactions on Knowledge and Data } \\
\text { Engineering }\end{array}$ & 6 & 0 & 6 \\
\hline IEEE Transactions on Software Engineering & 11 & 0 & 11 \\
\hline Information \& Management & 8 & 0 & 8 \\
\hline Information Systems Research & 1 & 5 & 6 \\
\hline Journal of Management Information Systems & 3 & 4 & 7 \\
\hline Management Science & 1 & 4 & 5 \\
\hline MIS Quarterly & 2 & 7 & 9 \\
\hline MIT Sloan Management Review & 1 & 5 & 6 \\
\hline Organization Science & 1 & 4 & 5 \\
\hline
\end{tabular}




\begin{tabular}{|l|c|c|c|c|}
\hline \multicolumn{1}{|c|}{$\begin{array}{c}\text { TABLE 4 } \\
\text { Database Coverage of Selected Journals (N = 20) }\end{array}$} \\
\hline \hline \multicolumn{1}{|c|}{ Database Name } & $\begin{array}{c}\text { Journals } \\
\text { Indexed Only } \\
\text { (no.) }\end{array}$ & $\begin{array}{c}\text { Journals } \\
\text { Full Text } \\
\text { (no.) }\end{array}$ & $\begin{array}{c}\text { Total } \\
\text { Covered } \\
\text { (no.) }\end{array}$ & Rank \\
\hline ABI/INFORM Global & 6 & 12 & 18 & 4 \\
\hline Academic Search Premier & 7 & 0 & 7 & 10 (tie) \\
\hline Applied Science \& Technology Full Text & 7 & 0 & 7 & 10 (tie) \\
\hline Business \& Company Resource Center & 4 & 13 & 17 & 5 \\
\hline Business Source Premier & 6 & 14 & 20 & 1 \\
\hline Computer Database & 2 & 5 & 7 & 9 \\
\hline Computer Source & 7 & 3 & 10 & 8 \\
\hline Expanded Academic Index & 7 & 13 & 20 & 2 \\
\hline Factiva & 8 & 3 & 11 & 7 \\
\hline LexisNexis Academic & 0 & 0 & 0 & 12 \\
\hline ProQuest Research Library & 4 & 7 & 11 & 6 \\
\hline Web of Science & 20 & 0 & 20 & 3 \\
\hline
\end{tabular}

total count across all databases; this line can be used to gauge relative performance among databases more easily than the raw numbers. The rankings shown in the third line are provided simply to assist the reader in quickly identifying the highest and lowest performers. The two databases with the most coverage are ABI/INFORM Global and Business Source Premier. They offer significantly more coverage than the third-ranked database, Web of Science. Overall, the business databases outperformed the multidisciplinary databases, which in turn outperformed the computer science-related databases. Factiva, a business database, is a noted exception with its poor performance.

One explanation of the results is the presence of extensive backfiles in both ABI/INFORM Global and Business Source Premier. How do the databases perform when looking only at more recent coverage? To answer that question, the authors used the same methodology and limited the results to articles from 2000 or later. The results are seen in the next section of table 5. Looking only at more recent articles, there is a slight shift in the results. ABI/INFORM Global drops to the fourth position, behind Business Source Premier, Business \& Company Resource Center, and Web of Science, in that order. However, these four databases and the fifth-ranked database, Expanded Academic Index, are clustered fairly closely. With the effects of the backfiles removed, the results are distributed more evenly across the databases. The overall pattern remains, with business databases outperforming the other categories.

The journals under consideration, though being those of most importance as publication outlets, are not equal in importance. However, the investigation so far has treated them equally. A database that covers only the less important journals may have outscored a database that covers only the more important journals if it covers them more intensively or there are simply more articles in the less important journals. To explore this situation, the totals were computed again using only the five highest-rated journals on the list: MIS Quarterly, Information Systems Research, Communications of the ACM, Journal of Management Information Systems, and Management Science. These results appear in the lower section of 
Database Coverage for Research in Management Information Systems 57

\begin{tabular}{|c|c|c|c|c|c|c|c|c|c|c|c|c|c|c|c|}
\hline & $\hat{\theta}$ & & $\begin{array}{l}2 \\
0 \\
0 \\
0 \\
\tilde{v} \\
\sim\end{array}$ & $\begin{array}{l}\stackrel{0}{\oplus} \\
\stackrel{m}{=}\end{array}$ & $m$ & $\left|\begin{array}{c}\mathcal{V} \\
\mathcal{N} \\
\infty \\
\infty\end{array}\right|$ & $\mid \begin{array}{l}\stackrel{0}{i} \\
\dot{m} \\
-1\end{array}$ & $m$ & & \begin{tabular}{l}
0 \\
\multirow{0}{0}{} \\
$a$
\end{tabular} & $\frac{\partial^{0}}{a}$ & $\nabla$ & 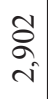 & $\frac{\partial}{\stackrel{2}{2}}$ & $m$ \\
\hline & $\stackrel{U}{\underline{\underline{z}}}$ & & 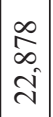 & 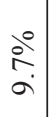 & $n$ & $\left|\begin{array}{c}2 \\
0 \\
n \\
n\end{array}\right|$ & $\begin{array}{l}\stackrel{0}{\circ} \\
\infty\end{array}$ & 0 & & $\begin{array}{l}n \\
\nabla_{0}^{n} \\
6\end{array}$ & 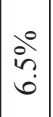 & $\infty$ & $\begin{array}{l}\stackrel{0}{ } \\
\stackrel{-}{-}\end{array}$ & 吕 & $\infty$ \\
\hline & 帘 & & 0 & $\begin{array}{l}\stackrel{0}{0} \\
\text { ○े }\end{array}$ & $\simeq$ & 0 & $\begin{array}{l}\text { ठें } \\
\text { ठे }\end{array}$ & $\simeq$ & & 0 & $\begin{array}{l}0 \\
\dot{0} \\
0\end{array}$ & $\simeq$ & 0 & 官 & $\simeq$ \\
\hline & 胥 & & 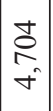 & $\begin{array}{l}\stackrel{0}{0} \\
\text { ì } \\
\text { in }\end{array}$ & $=$ & $\begin{array}{c}\circ \\
\infty \\
\sim \\
\text { ñ } \\
\end{array}$ & $\begin{array}{l}\text { iे } \\
\text { in }\end{array}$ & $\infty$ & & 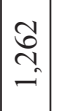 & @̊ & $=$ & $\begin{array}{l}\infty \\
\stackrel{n}{=} \\
=\end{array}$ & $\begin{array}{l}\stackrel{0}{\infty} \\
\dot{+}\end{array}$ & 으 \\
\hline$\stackrel{\mathscr{\varrho}}{\tilde{J}}$ & 紊 & & 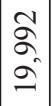 & $\begin{array}{l}\stackrel{0}{ } \\
i n \\
\infty\end{array}$ & 6 & 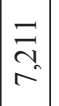 & $\begin{array}{l}\stackrel{0}{0} \\
\text { di } \\
\text { I }\end{array}$ & $n$ & & $\begin{array}{c}\stackrel{3}{*} \\
\stackrel{n}{n}\end{array}$ & $\begin{array}{l}\dot{0} \\
\dot{b} \\
r\end{array}$ & $r$ & $\begin{array}{l}\overrightarrow{0} \\
n \\
i\end{array}$ & $\stackrel{\circ}{\stackrel{0}{2}}$ & $\nabla$ \\
\hline$\stackrel{\infty}{\Sigma}$ & 令 & & 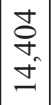 & $\frac{0^{0}}{\theta^{\circ}}$ & $r$ & $\left|\begin{array}{c}\tilde{N} \\
\infty \\
n \\
\sim \\
n\end{array}\right|$ & $\begin{array}{l}80 \\
\dot{0} \\
\dot{0}\end{array}$ & $r$ & & $\begin{array}{l}\hat{\alpha} \\
\hat{\sigma}\end{array}$ & $\frac{\partial^{0}}{\dot{0}}$ & $m$ & $\begin{array}{l}n \\
n \\
n \\
i\end{array}$ & ळें & $\underbrace{\stackrel{g}{\Theta}}_{n}$ \\
\hline 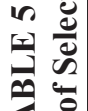 & है & & 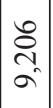 & $\begin{array}{l}\stackrel{0}{े} \\
\dot{m}\end{array}$ & $a$ & $\left|\begin{array}{l}\infty \\
\sim \\
n \\
\sim\end{array}\right|$ & $\begin{array}{l}\stackrel{\circ}{े} \\
\stackrel{+}{+}\end{array}$ & 으 & & $\begin{array}{l}\stackrel{0}{n} \\
i n\end{array}$ & $\begin{array}{l}\partial^{0} \\
\infty \\
i \\
i\end{array}$ & $a$ & 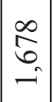 & 울 & $a$ \\
\hline نे & U્ત & & $\begin{array}{l}\stackrel{J}{ \pm} \\
\stackrel{\sim}{\sim} \\
\stackrel{\sim}{v}\end{array}$ & $\begin{array}{l}0 \\
\stackrel{0}{0} \\
0 \\
0\end{array}$ & $\nabla$ & $\begin{array}{l}n \\
2 \\
\infty \\
\infty\end{array}$ & $\begin{array}{l}0 \\
\infty \\
\dot{0} \\
-\end{array}$ & $N$ & & 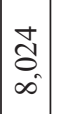 & $\frac{\partial^{0}}{\infty}$ & 0 & $\begin{array}{l}n \\
\tilde{n} \\
i\end{array}$ & ळ̊ํ & $\underbrace{\stackrel{0}{\Xi}}_{n}$ \\
\hline 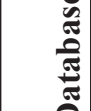 & $\overrightarrow{\tilde{\omega}}$ & & $\begin{array}{c}\infty \\
\underset{\sim}{ } \\
\stackrel{f}{f}\end{array}$ & $\frac{\partial}{2}$ & $N$ & $\begin{array}{c}\hat{\alpha} \\
\underset{+}{+} \\
\infty\end{array}$ & 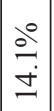 & - & & $\begin{array}{l}0 \\
\mathbb{1} \\
0 \\
0\end{array}$ & 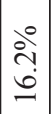 & $N$ & $\begin{array}{l}8 \\
8 \\
\circ \\
\text { ri }\end{array}$ & $\begin{array}{l}\text { i̊j } \\
\text { ì } \\
\text { in }\end{array}$ & $\sim$ \\
\hline & 는 & & $\begin{array}{l}\vec{J} \\
\sim \\
\sim\end{array}$ & $\frac{\partial^{0}}{\frac{\dot{m}}{m}}$ & $ㅇ$ & $\begin{array}{l} \pm \\
\overrightarrow{2} \\
i\end{array}$ & $\frac{\stackrel{0}{\grave{n}}}{\dot{m}}$ & $=$ & & $\begin{array}{l}\tilde{\infty} \\
\tilde{n} \\
m\end{array}$ & $\begin{array}{l}\stackrel{0}{\dot{y}} \\
\dot{y} \\
\stackrel{1}{2}\end{array}$ & 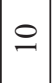 & $\stackrel{R}{R}$ & $\stackrel{\circ}{\stackrel{\circ}{n}}$ & $=$ \\
\hline & 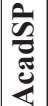 & & $\begin{array}{l}\infty \\
\vec{m} \\
\stackrel{m}{=}\end{array}$ & $\begin{array}{l}\dot{0} \\
\dot{b} \\
i \\
\end{array}$ & $\infty$ & $\begin{array}{c}\text { ֻે } \\
\text { } \\
m\end{array}$ & $\begin{array}{l}\partial_{0}^{0} \\
i \\
i n\end{array}$ & $a$ & & $\begin{array}{c}\bar{\sigma} \\
\infty\end{array}$ & 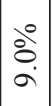 & in & 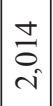 & $\underset{\infty}{\stackrel{0}{+}}$ & $r$ \\
\hline & 象 & & \begin{tabular}{c}
$\mathbb{N}$ \\
$\stackrel{N}{*}$ \\
\multirow{+}{*}{}
\end{tabular} & $\begin{array}{l}0 \\
\dot{b} \\
\dot{0} \\
\dot{i}\end{array}$ & - & 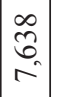 & $\begin{array}{l}\stackrel{0}{i} \\
\stackrel{i}{c}\end{array}$ & $\nabla$ & & $\begin{array}{l}\overrightarrow{\widetilde{V}} \\
\mathbb{N} \\
\tilde{N}\end{array}$ & $\begin{array}{l}\stackrel{0}{\partial} \\
\grave{~}\end{array}$ & - & $\underset{m}{\stackrel{\Xi}{m}}$ & $\frac{\stackrel{0}{2}}{\ddot{n}}$ & - \\
\hline & & 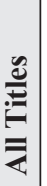 & 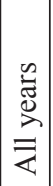 & 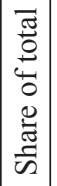 & 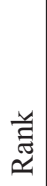 & 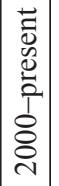 & 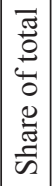 & 䓌 & 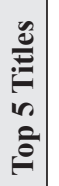 & 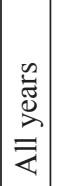 & 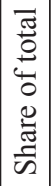 & 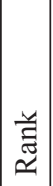 & 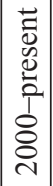 & 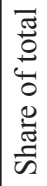 & 光 \\
\hline
\end{tabular}

table 5. When considering coverage for all years, ABI/INFORM Global provides the greatest amount of coverage by a wide margin, with Business Source Premier following. Computer Source moves well forward in the rankings to replace Web of Science in the third position. Academic Search Premier also shows a higher ranking. When counting only articles from 2000 or later, ABI/ INFORM Global continues to provide the greatest amount of coverage, but by a smaller margin. Business Source Premier and Web of Science are second and third. Expanded Academic Index achieves its highest ranking in this category. Overall, results are distributed more evenly across the databases. For both time periods, two business databases provide the best coverage. In general, business databases provide the greatest amount of coverage, followed by multidisciplinary databases and then the computer science-related databases. An exception is Computer Source, which advanced in the rankings for both time periods. 


\section{Database Coverage of Resources for MIS Research}

The second part of the study focuses on the resources needed for MIS research. As described earlier, MIS scholars potentially may draw from several other disciplines in conducting their research. To derive a more accurate picture of which databases provide good support for MIS research, the authors elected to collect a sample of actual references used by MIS scholars and then test it against the selected databases. This required a method for identifying MIS articles within non-MIS journals or an approach for identifying journals that primarily publish articles on MIS. To address this problem, the authors turned again to the Walstrom and Hardgrave survey. Another question in the survey asked respondents to indicate whether each journal published primarily information systems research. A positive response was coded as one and a negative response as zero, and scores were computed for each title. Three journals received unanimously positive responses (overall score of 1.00): Information Systems Research, Journal of Management Information Systems, and MIS Quarterly. ${ }^{24}$

The authors collected the references from every article in each issue of the three journals for the period 2000 through 2002. All items with references from those issues were included. The references to journal articles then were extracted to form a list of 9,117 citations. A random sample of 369 citations was taken for a confidence level of 95 percent and a confidence interval of plus or minus 5 percent. The sample was sorted by journal title and date, and then each citation was searched in each database. The citations were coded according to their status in the database (not included, indexing only, or full text).

The 369 citations in the sample represent 148 different journal titles; 98 of the titles were referenced only once. Table 6 shows a list of the most frequently referenced titles in the sample. The most frequently referenced journal was MIS Quarterly, with thirty-six citations; Information Systems Research was second with twenty-one citations and Journal of Management Information Systems was third with eighteen. Self-citation bias could account for these three titles being the most cited. The next most-cited titles were Management Science with sixteen references, Communications of the ACM with thirteen, and Harvard Business Review with ten. Seventeen of the twenty journals listed in table 1 appeared in the sample under the current title or a previous title. The oldest article cited was published in 1951 and the most recent in 2002; the median publication date for the sample was 1992 (i.e., half the articles were published in the period 1951 to 1992 and half were published from 1992 to 2002).

Table 7 shows the coverage of the sample articles in each of the databases. Business Source Premier provides the most comprehensive coverage, with indexing or full text of 69.4 percent of the sample articles. ABI/INFORM Global is a close second, with 68.0 percent, and Web of Science is third with 58.8 percent. These are the only databases that cover over half the sample. The other business databases performed less well, with Business \& Company Resource Center covering 46.1 percent and Factiva only

\begin{tabular}{|c|c|}
\hline \multicolumn{2}{|c|}{$\begin{array}{c}\text { TABLE } 6 \\
\text { Journals in the Sample Referenced } 10 \\
\text { or More Times }\end{array}$} \\
\hline Journal Title & $\begin{array}{c}\text { Number of Times } \\
\text { Referenced }\end{array}$ \\
\hline MIS Quarterly & 36 \\
\hline $\begin{array}{l}\text { Information Systems } \\
\text { Research }\end{array}$ & 21 \\
\hline $\begin{array}{l}\text { Journal of Management } \\
\text { Information Systems }\end{array}$ & 18 \\
\hline Management Science & 16 \\
\hline $\begin{array}{l}\text { Communications of the } \\
\text { ACM }\end{array}$ & 13 \\
\hline Harvard Business Review & 10 \\
\hline
\end{tabular}




\begin{tabular}{|l|c|c|c|c|}
\hline \multicolumn{5}{|c|}{$\begin{array}{c}\text { TABLE 7 } \\
\text { Database Coverage of References by MIS Researchers }\end{array}$} \\
\hline \hline Database & $\begin{array}{c}\text { Full Text } \\
(\%)\end{array}$ & Rank & $\begin{array}{c}\text { Total Coverage } \\
\text { indexed or full } \\
\text { text) (\%) }\end{array}$ & Rank \\
\hline Business Source Premier & 51.2 & 1 & 69.4 & 1 \\
\hline ABI/INFORM Global & 39.3 & 2 & 68.0 & 2 \\
\hline Web of Science & 0.0 & 11 (tie) & 58.8 & 3 \\
\hline Expanded Academic Index & 15.7 & 6 & 49.6 & 4 \\
\hline $\begin{array}{l}\text { Business \& Company Resource } \\
\text { Center }\end{array}$ & 16.8 & 5 & 46.1 & 5 \\
\hline ProQuest Research Library & 17.6 & 4 & 31.7 & 6 \\
\hline Computer Source & 20.6 & 3 & 27.9 & 7 \\
\hline Academic Search Premier & 12.5 & 7 & 19.0 & 8 \\
\hline Computer Database & 8.9 & 8 & 18.2 & 9 \\
\hline Applied Science \& Technology & 0.0 & 11 (tie) & 10.3 & 10 \\
\hline Factiva & 7.3 & 9 & 9.8 & 11 \\
\hline LexisNexis Academic & 1.1 & 10 & 1.1 & 12 \\
\hline
\end{tabular}

9.8 percent of the sample. Among the multidisciplinary databases, Expanded Academic Index covered 49.6 percent, ProQuest Research Library covered 31.7 percent, and Academic Search Premier covered 19.0 percent. Business Source Premier and Academic Search Premier are both produced by EBSCO Information Services, so it is surprising to see that the multidisciplinary database covered significantly less of the sample than most of the other multidisciplinary databases. From that group, only LexisNexis Academic had poorer results, with only 1.1 percent coverage. The computer science databases offered limited coverage, ranging from Computer Source with 27.9 percent coverage to Applied Science and Technology with 10.3 percent coverage.

The results for full-text coverage also are shown in table 7. In this category, Business Source Premier is dominant, offering full text for just over half of the articles in the sample. ABI/INFORM Global is second with 39.3 percent full text. The remaining databases have rather poor coverage, ranging from Computer Source with 20.6 percent down to LexisNexis Aca- demic with 1.1 percent, followed by the two databases that do not offer full text.

Forty-seven of the 369 sample articles, or 12.7 percent, were not found in any of the databases. The dates of these articles ranged from 1951 through 2000. Most of the articles were distributed fairly evenly over the period 1970 through 2000, although there was a concentration of articles from the early 1980s. The median date was 1983 (i.e., half the articles were dated from 1983 or before and half were dated 1983 or later). The forty-seven articles appeared in thirty-nine distinct journals. About a third were psychology journals, and several journals were from management or business fields and from information systems or computer-related fields. The remaining journals represented a variety of subjects, including education and law.

As table 7 indicates, the best performing database, Business Source Premier, contained coverage for less than threequarters of the citations. However, 87.3 percent of the sample articles were found in at least one of the databases. As a next step, the authors looked at pairings of 


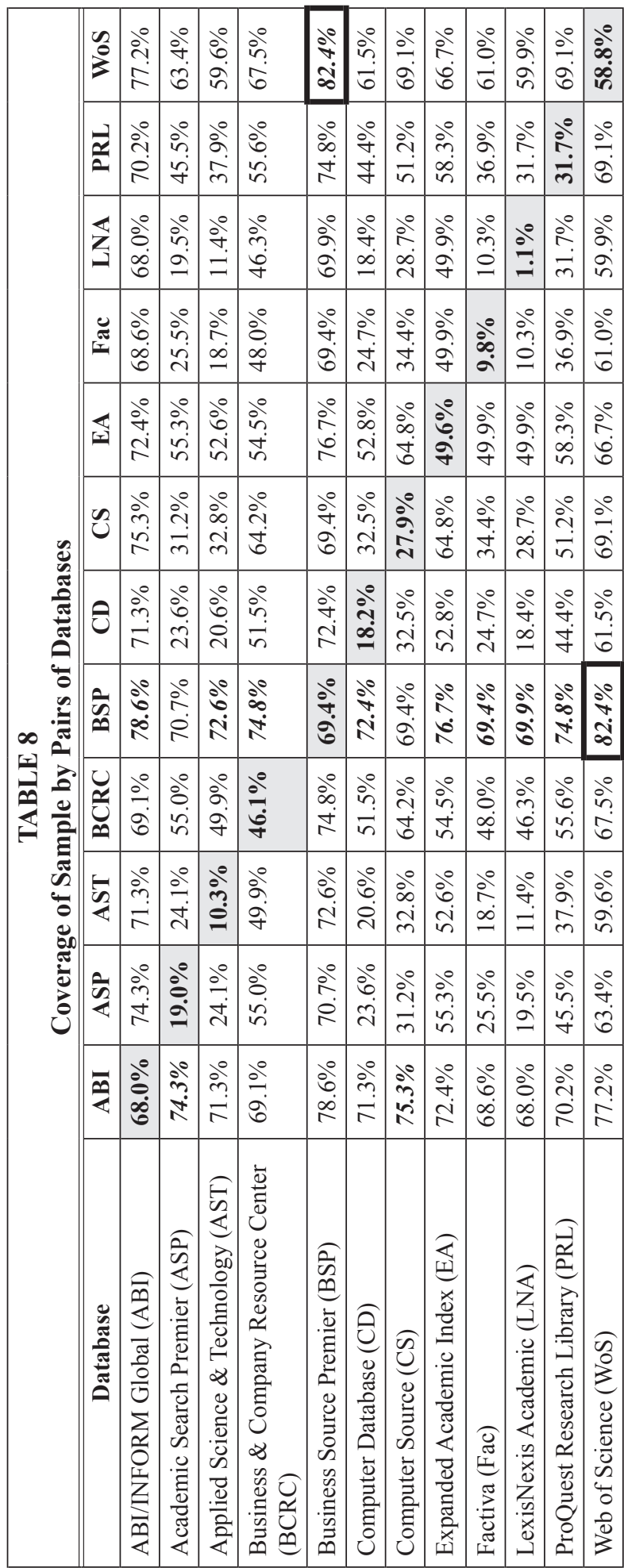

databases to determine which two combined would give the most complete coverage of the articles in the sample. The results are shown in table 8. The cell at the intersection of a row and a column gives the amount of coverage for that combination of databases. To assist the reader, the cells on the diagonal have a gray background; these cells represent a pairing of each database with itself, which provides a baseline for comparing to what extent coverage is improved when combining with other databases. The highest percentage in each row is presented in bold and italics, indicating which database can be combined with the database for that row to provide the best results. Finally, a box highlights the highest percentage in the table, indicating the combination of databases that provides the best coverage of the sample articles.

According to table 8, the pair of databases providing the most comprehensive coverage of the sample articles is Business Source Premier and Web of Science. These two databases provide coverage of 82.4 percent of the sample. The second best combination is Business Source Premier and ABI/INFORM Global, for coverage of 78.6 percent. In fact, most of the databases among those tested 
show the best results when combined with Business Source Premier. The two exceptions, Academic Search Premier and Computer Source, are databases from the same vendor as Business Source Premier. For those databases, better results are obtained when combined with a database from a different vendor. Databases from a different vendor are likely to include coverage of publishers and sources not available to the first vendor.

\section{Discussion}

For coverage of journals that publish MIS research, ABI/INFORM Global and Business Source Premier are the best databases. These two databases rank first and second in coverage of both the full-title list and the top five journals for all years and for the top five journals for articles from 2000 to present. ABI/INFORM Global's ranking drops somewhat when considering coverage of the full list for articles from 2000 to the present. For coverage of articles referenced by MIS researchers, their positions are reversed, with Business Source Premier outperforming ABI/INFORM Global by a small margin. However, Business Source Premier offers significantly more full text of the articles in the sample than any other databases tested.

When combining the coverage of two databases, the best results are obtained by searching Business Source Premier and Web of Science. Almost all the databases gave their best results when combined with Business Source Premier. As discussed earlier, the two exceptions are databases from the same vendor. Even ABI/INFORM Global shows its best performance when combined with Business Source Premier, indicating that, despite their similar performance in the rankings of individual databases, there are differences in their coverage.

It is interesting to note that the database providing the most full-text coverage of articles in the sample, Business Source Premier, offered full text for only about half the articles. The pair of databases offering best overall coverage, Business Source Premier and Web of Science, would not increase that figure because Web of Science does not include any full text. Fortunately, tools are becoming more widely available that allow a library to configure databases so users can link from a bibliographic record in one vendor's database to a record with full text in another vendor's database or at a publisher's Web site. Thus, the amount of electronic full text actually available to the researcher will be determined by the range of databases offered and the online journal holdings of the library.

\section{Conclusion}

The purpose of this study is to assess database coverage of both the published output of MIS researchers and the journal resources they use to support their research. Results show that indexing of both types of materials is fairly extensive. The findings also indicate that two databases, ABI/INFORM Global and Business Source Premier, provide the most comprehensive coverage for each. In addition, Business Source Premier offers full text for the greatest number of MIS journals and provides the greatest amount of full text for journal articles referenced by MIS researchers.

MIS researchers currently draw resources from many subject areas, and many of the publications considered important outlets for publication of MIS research are journals in other fields, such as management and computer science. As MIS continues to mature as a discipline, it will be interesting to observe how MIS research evolves. Databases are continuously changing as well, so future studies may show better coverage of this complex field by nonbusiness databases.

\section{Notes}

1. William R. King, "Management Information Systems," in Encyclopedia of Information Systems, 
vol. 3, ed. Hossein Bidgoli, 115 (New York: Academic Pr., 2003).

2. A. S. Lee, "MIS Quarterly's Editorial Policies and Practices," MIS Quarterly 25, no. 1 (2001): iii.

3. Richard O. Mason and James L. McKenney, "Developing an Historical Tradition in MIS Research," MIS Quarterly 21, no. 3 (1997): 258.

4. Ibid., 259.

5. "Association for Information Systems: About AIS," Association for Information Systems, 2001. [Accessed 8 November 2004] . Available online at www.aisnet.org/admin.shtml.

6. ISWorld Net Home Page, Association for Information Systems, 2004. [Accessed 8 November 2004]. Available online at www.isworld.org.

7. Richard L. Baskerville and Michael D. Myers, "Information Systems as a Reference Discipline," MIS Quarterly 26, no. 1 (2002): 3.

8. Ibid., $1-14$.

9. Iris Vessey, V. Ramesh, and Robert L. Glass, “Research in Information Systems: An Empirical Study of Diversity in the Discipline and the Journals," Journal of Management Information Systems 19, no. 2 (2002): 129-74.

10. Karen Chapman and Paul Brothers, "A Reference Study of Leading MIS Journals: Identifying Formats, Frequency, and Journal Subjects," Journal of Business \& Finance Librarianship, 10, no.2 (2004):17-29.

11. Steve Black, "An Assessment of Social Sciences Coverage by Four Prominent Full-text Online Aggregated Journal Packages," Library Collections, Acquisitions, \& Technical Services 23, no. 4 (1999): 411-19. $27-37$.

12. Michael Colby, "Music Periodical Indexing in General Databases," Notes 54 (1997):

13. Péter Jacsó, "Analyzing the Journal Coverage of Abstracting/Indexing Databases at Variable Aggregate and Analytic Levels," Library \& Information Science Research 20, no.2 (1998): 133-51.

14. Karen Chapman, "Full-Text Database Support for Scholarly Research in Finance," Journal of Business \& Finance Librarianship 7, no. 4 (2002): 35-44.

15. William H. Walters and Esther I. Wilder, "Bibliographic Index Coverage of a Multidisciplinary Field," Journal of the American Society for Information Science and Technology 54, no. 14 (2003): 1305-12.

16. Jing Hu, Lai C. Liu, Kai S. Koong, and Lillian Fok, "Information Systems Journals: A Study of University Library Holdings," Journal of Business \& Finance Librarianship 8, no. 1 (2002): 27-43.

17. Chapman and Brothers, "A Reference Study of Leading MIS Journals."

18. Carol Saunders, ed., "Journal Rankings," Association for Information Systems. [Accessed 8 November 2004]. Available online at www.isworld.org/csaunders/rankings.htm.

19. For an example of a study using a survey, see Nikolaos A. Mylonopoulos and Vasilis Theoharakis, "Global Perceptions of IS Journals: Where Is the Best IS Research Published?" Communications of the ACM 44, no. 9 (2001): 29-33; for an example of a study using citation analysis, see Randolph B. Cooper, David Blair, and Miranda Pao, "Communicating MIS Research: A Citation Study of Journal Influence," Information Processing \& Management 29, no. 1 (1993): 113-27.

20. Saunders, "Journal Rankings."

21. Kent A. Walstrom and Bill C. Hardgrave, "Forums for Information Systems Scholars: III," Information \& Management 39 (2001): 117-24.

22. Elaine Wagner, "Multidisciplinary Searching for Comprehensive Retrieval," Georgia Library Quarterly 35, no. 1 (1998): 4.

23. Jacsó, "Analyzing the Journal Coverage of Abstracting/Indexing Databases at Variable Aggregate and Analytic Levels."

24. Walstrom and Hardgrave, "Forums for Information Systems Scholars," 120. 